\title{
Development of guidelines for fitness training based on local wisdom of the Malind Tribe to victims of drug abuse
}

\author{
Arifin Ika Nugroho* ${ }^{\circledR}$, Hendra Jondry Hiskya ${ }^{\circledR}$, Carolus Wasa ${ }^{\circledR}$, Jori Lahinda
}

\author{
Universitas Musamus, Indonesia
}

Received: 10 November 2020; Accepted 23 May 2021; Published 03 August 2021

Ed 2021; 6(2): 275-285

\begin{abstract}
Drug abuse is a social problem with a very wide negative impact and in its recovery it needs several solutions. The emphasis of the discussion in this study is the fact in the field that it shows the pattern of implementation of physical and health guidance so far it has only been an unstructured, measurable, and comprehensive implementation. The research is aimed at developing fitness training guidelines and healthy lifestyles based on local wisdom for victims of drug use that are feasible and effective, which will be provided to victims of drug use in the border communities of Indonesia-Papua New Guinea, Merauke Papua. The method used in this research is the Research and Development method, it is chosen as a method for producing certain products and testing the effectiveness of the products to be developed, namely guidelines for fitness training and healthy lifestyles based on local wisdom for drug use victims. The steps of data collection techniques in this research are preliminary study, planning, initial draft, draft trial, small and large scale data, final product, and effectiveness test (Cooper test-12 minutes). The population in this study amounts to 20 people consisting of officers/practitioners in indigenous communities/villages and victims of drug abuse in the Indonesian-Papua New Guinea Border Community, Merauke Papua. The sampling technique in this study uses purposive sampling. The data analysis technique used in this research is quantitative descriptive analysis and descriptive analysis. The results of the study show the feasibility and effectiveness of developing guidelines for fitness training and healthy living patterns based on local wisdom that can be used for drug use victims in the border communities of RI-PNG Merauke Papua.
\end{abstract}

Keywords: Fitness; training; drugs; local culture

https://doi.org/10.25299/sportarea.2021.vol6(2).5817
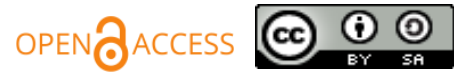

Copyright @ 2021 Arifin Ika Nugroho, Hendra Jondry Hiskya, Carolus Wasa, Jori Lahinda

Corresponding author: Arifin Ika Nugroho, Department of Physical Education, Health and Recreation, Faculty of Teacher Training and Education, Universitas Musamus, Merauke, Indonesia

Email: arifin@unmus.ac.id

How to Cite: Nugroho, A. I., Hiskya, H. J., Wasa, C., \& Lahinda, J. (2021). Development of fitness training guidelines based on local wisdom of the Malind Tribe for victims of drug abuse. Journal Sport Area, 6(2), $275-285$. https://doi.org/10.25299/sportarea.2021.vol6(2).5817

\section{INTRODUCTION}

Drug abuse is a social problem whose negative impact is very broad and in its recovery it needs several solutions including intervention in social guidance activities, religious and spiritual guidance, vocational guidance and physical and health guidance activities (Anggraeni et al., 2017). The data shows, according to the level of dependence on drug abuse, the estimated number of drug abuse in Indonesia in 2014 was the highest among workers with the trial category then the regular category (Kalfa et al., 2012). Several cases also occurred in customary areas in Papua, especially Merauke Regency, many indigenous people in their daily life coexist with alcohol and the environment strongly supports its distribution from the Muli Strait (Mariane 
Strait) to the borders of Papua and Papua New Guinea (Yarman, 2013). Therefore, various negative impacts began to emerge, including victims of drug abuse from adolescence to adulthood starting to feel complaints due to the use of these substances (Azmiyati, 2014).

Together we understand the current conditions that the modern day drug abuse recovery program is very important for victims who experience it, where handling and assistance from the environment and family also have various types of approaches (Kalfa et al., 2012), this process is only one of the many efforts to overcome the drug problem, including starting from the pattern of prevention, development to further guidance for addicts for their recovery (Lahinda et al., 2020). Recovery programs that have multiple approaches have shown success in helping addicts go through the recovery process, especially if they follow the program as a whole (Nainggolan, 2011; Osborne et al., 2016).

The emphasis of the discussion in this study is on field facts that show the pattern of implementation of physical and health guidance so far is only an implementation that has not been structured, measured, and comprehensive (Nugroho et al., 2020). Researchers also found that there is a lack of formation of patterns of carrying out sports activities that can force them to join together in a daily schedule that people can learn on their own. In accordance with the results of the study show that short exercise-based addiction rehabilitation and consultation tailored to the health habits of adolescents, with and without parent material, has the potential to reduce alcohol use while increasing exercise frequency (Werch, Moore, DiClemente, Owen, Jobli, \& Bledsoe, 2003; Kalfa et al., 2012).

Looking at the conditions above, it's certainly difficult to get a good level of fitness during an addict's recovery (Malonda et al., 2012). Some experts also state that exercise is one way to channel nerves (brain neurotransmitters) in the brain, by giving a positive impact in the brain so that the body experiences a healthy life in peace (Sukadiyanto \& Muluk, 2011). Khan (2014) showed that there was a significant improvement due to twelve weeks of physical exercise and others. Strengthening must be carried out on all patterns of implementing interventions that have been listed in the implementation guidelines that have been prepared by the Central Government (Afriwardi, 2011). Product development of teaching modules for fitness training program guidelines for victims of drug abuse shows the level of feasibility, validity, and effectiveness (benefits) (Tritama, 2015).

The specific objective of this research is to provide an alternative in the recovery process for victims of drug abuse in the Marind Tribe by using a fitness exercise program guideline and a healthy lifestyle based on local wisdom consistently, regularly, and independently. The urgency of the research is to develop guidelines for fitness activities in the recovery process using fitness training programs and a healthy lifestyle based on local wisdom for victims of drug abuse in the Marind Tribe community on the RI-PNG border, which can be learned by all parties is that the implementation of physical guidance activities has not been maximized and health, as well as the absence of guidelines for fitness training programs and healthy lifestyles related to applicable activities, the implementation of which is comprehensive, regular, measurable and can be done independently or with the assistance of the relevant office. The problem that most often encountered is based on the observations of researchers as rehabilitation practitioners, that the results of the physical fitness of victims of drug abuse are still low in the recovery process. Victims of drug abuse, the Marind Tribe community on the RI-PNG border, Merauke Regency, Papua Province became the subject of this research and they were given an alternative in the recovery process by using guidelines for fitness training programs and a healthy lifestyle based on the local wisdom of Malind Anim. Where local wisdom is a habit or system that integrates knowledge, culture, and institutions as well as the practice of managing natural resources that is easily understood by the local community (Yarman, 2013). Various research results show that alternative sports activities affect the formation of values, leadership, motivation and creativity, and can affect a person's life, because human life is influenced by physical, psychological and social (Calmels et al., 2004; Shen \& Chen, 2007; Osborne et al., 2016; Bostani \& Saiiari, 2011; Utina, 2012).

\section{METHOD}

The method in this research is research and development. The development procedure uses a design from (Sugiyono, 2011). The steps of the data collection technique in this study are described as follows: preliminary 
study, planning, initial draft design, trial draft, small and large scale data, final product, and effectiveness test. The instrument used to measure the effectiveness of the product is a fitness test using the Cooper Test - 12 Minutes (Giriwijoyo, 2017). This research is conducted on victims of drug abuse in the Malind Tribe at the RI-PNG Border (Kampung Yanggandur) Merauke Regency, Papua Province.

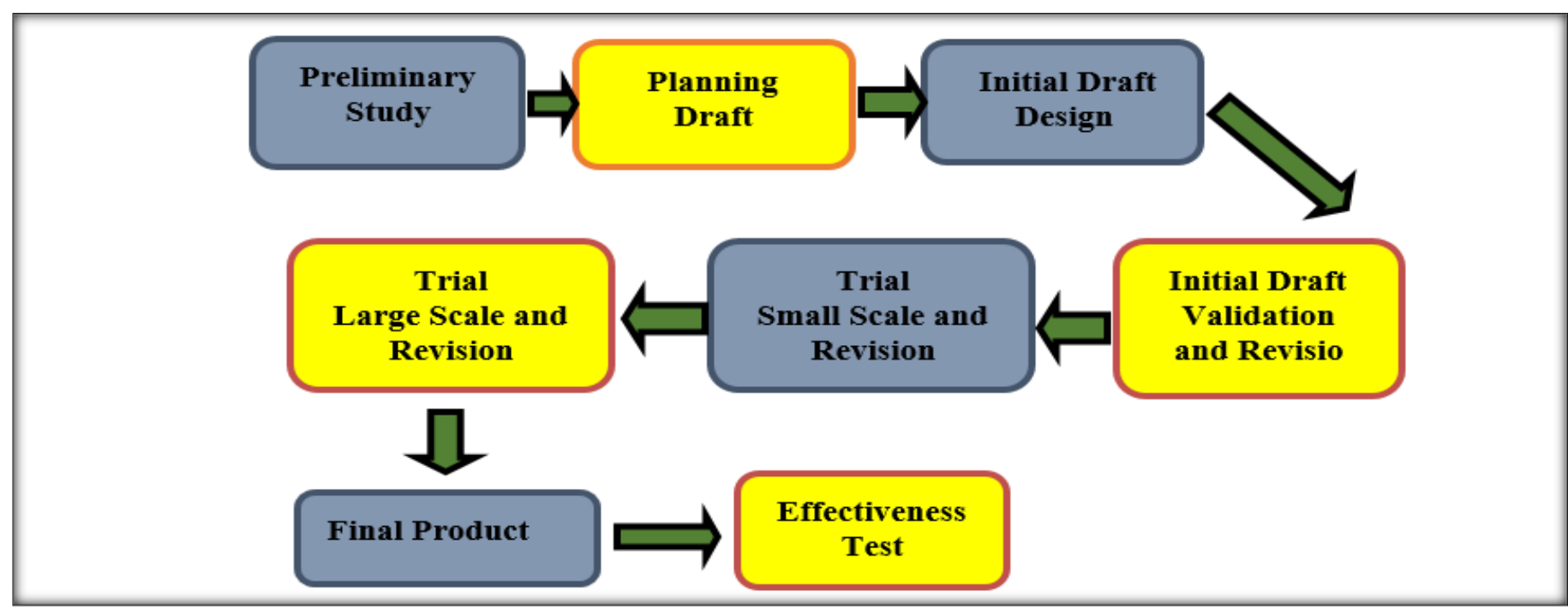

Figure 1. Diection of Development Research

The population in this study is victims of drug abuse by the Marind Tribe on the RI-PNG border, Merauke Regency, Papua Province. While the samples in this study are in the implementation of small-scale product trials carried out on 7 people and large-scale tests on 12 victims of drug abuse, as well as effectiveness testing on 20 people who abused drugs, the Malind Tribal Community at the RI-PNG border, Merauke Regency. Samples are taken using a purposive sampling technique by considering the age of 18-35 years and have or are using addictive substances in the last 1 month.

Table 1. Konversion of Assessment Based on Percentage

\begin{tabular}{llcc}
\hline No & Percentage & Score & Category \\
\hline 1 & $81 \%-100 \%$ & A & Very Good \\
2 & $61 \%-80 \%$ & B & Good \\
3 & $41 \%-60 \%$ & C & Good Enough \\
\hline
\end{tabular}

(Sugiyono,2011)

The instruments used in this study are: Interviews (questions arranged in the interview guide are adjusted to the purpose of the interview, namely to explore the spiritual, psychological, mental problems faced by victims and their families of drug abuse. Observation (Observation is one of collecting data to study the behavior and activities of victims of drug abuse). Assessment instruments for experts An assessment grid of materials and media products for experts is presented:

Table 2. Grid of Instrument for Material Experts

\begin{tabular}{cccc}
\hline No & Aspects & Item Number & Amount \\
\hline 1 & Strategy of Program Understanding & $1,2,3,4,5,6$ & 6 \\
2 & Content of Material & $7,8,9,10,11,12,13,14,15$ & 9 \\
\hline & Total & $\mathbf{1 5}$ & \\
\hline
\end{tabular}

Table 3. Grid of Instrument for Media Experts

\begin{tabular}{cccc}
\hline No & Aspects & Item Number & Amount \\
\hline 1 & Communication & $1,2,3,4,5,6$ & 6 \\
2 & Technique Design & $7,8,9,10,11,12,13,14,15,16,17$ & 11 \\
\hline & Total & $\mathbf{1 7}$ & \\
\hline
\end{tabular}


Table 4. Grid of Instrument for Trial Subject

\begin{tabular}{cccc}
\hline No & Aspects & Item Number & Amount \\
\hline 1 & Media Display & $1,2,3,4,5,6,7,8,9,10,11$ & 11 \\
2 & Content/Material & $12,13,14,15,16$ & 5 \\
\hline & Total & $\mathbf{1 6}$ & \\
\hline
\end{tabular}

The quantitative data analysis technique in this study uses descriptive statistical analysis, in the form of very poor, poor, good enough, good, very good statements which are converted into quantitative data with a scale of 5, namely by scoring from numbers 1 to 5 . The steps in data analysis includes: a.) collecting rough data, b.) scoring, c.) the scores obtained are then converted to a scale of 5. More clearly can be seen in table 5 .

Table 5. Criteria of Assesment

\begin{tabular}{cccc}
\hline Score & Criteria & Formula & Score \\
\cline { 2 - 4 } & & $\mathrm{X}>X i+1,8 S b i$ & $\mathrm{X}>4,21$ \\
$\mathrm{~A}$ & Very High & $\mathrm{Xi}+0,6 \mathrm{Sbi}<X \leq \mathrm{Xi}+1,8 \mathrm{Sbi}$ & $3,40<X \leq 4,21$ \\
$\mathrm{~B}$ & High & $\mathrm{Xi}-0,6 \mathrm{Sbi}<X \leq \mathrm{Xi}=0,6 \mathrm{Sbi}$ & $2,60<X \leq 3,40$ \\
$\mathrm{C}$ & Medium & $\mathrm{Xi}-1,8 \mathrm{Sbi}<X \leq \mathrm{Xi}-0,6 \mathrm{Sbi}$ & $1,79>X \leq 2,60$ \\
$\mathrm{D}$ & Low & $\mathrm{X} \leq \mathrm{Xi}-1,8 \mathrm{Sbi}$ & $\mathrm{X} \leq 1,79$ \\
$\mathrm{E}$ & Very Low & & \\
\hline
\end{tabular}

Rules:

Average ideal score (Xi)

Standard deviation of ideal score (SBi)

$\mathrm{X}$ ideal
: $1 / 2$ (Ideal maximum score + Ideal minimum score)

$: 1 / 6$ (Ideal maximum score - Ideal minimum score)

: Empirical Score (Score to be achieved)

\section{RESULT AND DISCUSSION}

Based on the steps of the research procedure adapted from Borg \& Gall, this research begins with data collection and analysis of information which then becomes the basis for making the product. The product developed in this research is a Guide to Fitness Exercise and Healthy Lifestyle based on Local Wisdom Malind Anim to Victims of Drug Abuse in the Marind Tribe Community at the RI-PNG Border, Merauke Regency, Papua Province. The initial product design that has been compiled is based on the wisdom of the malind anim tribal community against, totemism system, hunting system, enforcement of customary law and formal law for violations of conservation areas, cultivation of native plants and animals which are the totemism of indigenous peoples, training and assistance to the community on a sustainable basis so that guidelines for the Fitness Exercise and Healthy Lifestyle Program related to applicable activities can be arranged. The implementation is comprehensive, regular, measurable, and can be done independently or with assistance. The next stage is validated by experts to determine the feasibility of the product before being tested in the field. The initial product in the form of Guidelines for Fitness Exercises and Healthy Lifestyles based on Malind Anim Local Wisdom to Victims of Drug Abuse in the Marind Tribe Communities at the RI-PNG Border, which before being tested in small group trials needs to be validated by experts in accordance with this research field. Validation is done by submitting an initial product draft (Nugroho \& Fadlih, 2019), accompanied by an assessment sheet with a value scale in which there are inputs, suggestions, and revisions from experts. The results of the assessment are in the form of a value scale for the product using a score of 1-4. 


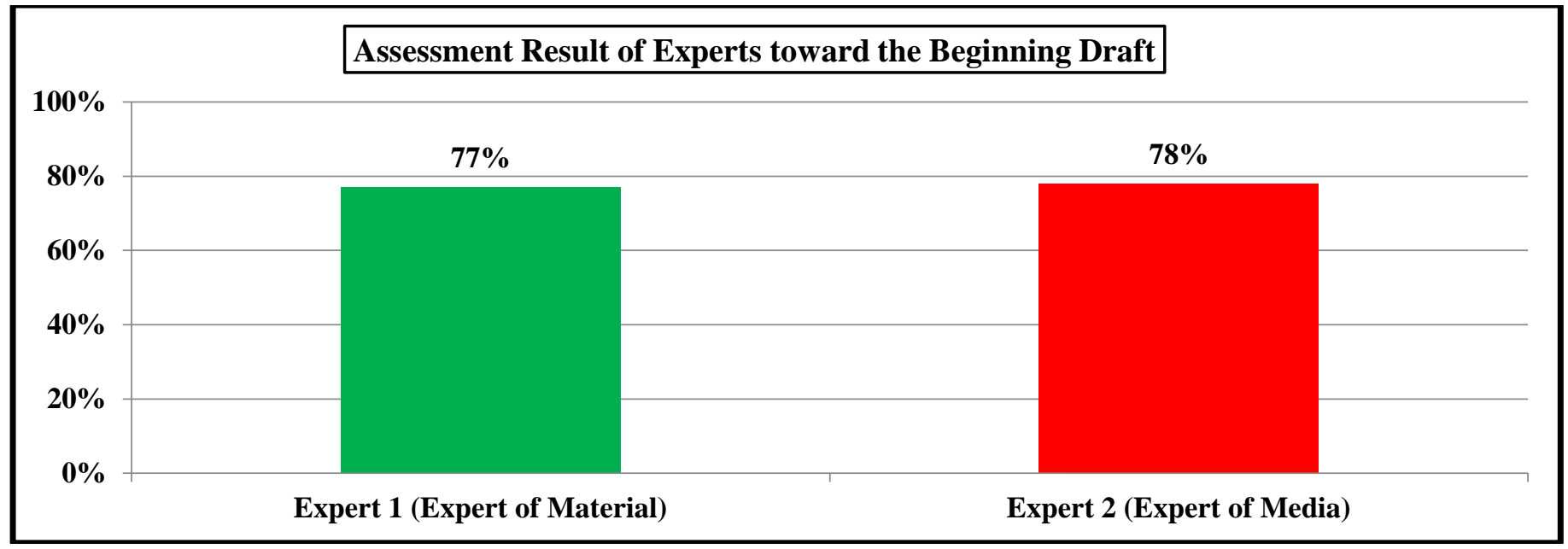

Graph 2. Assessment Result of Experts toward Product (Step 1)

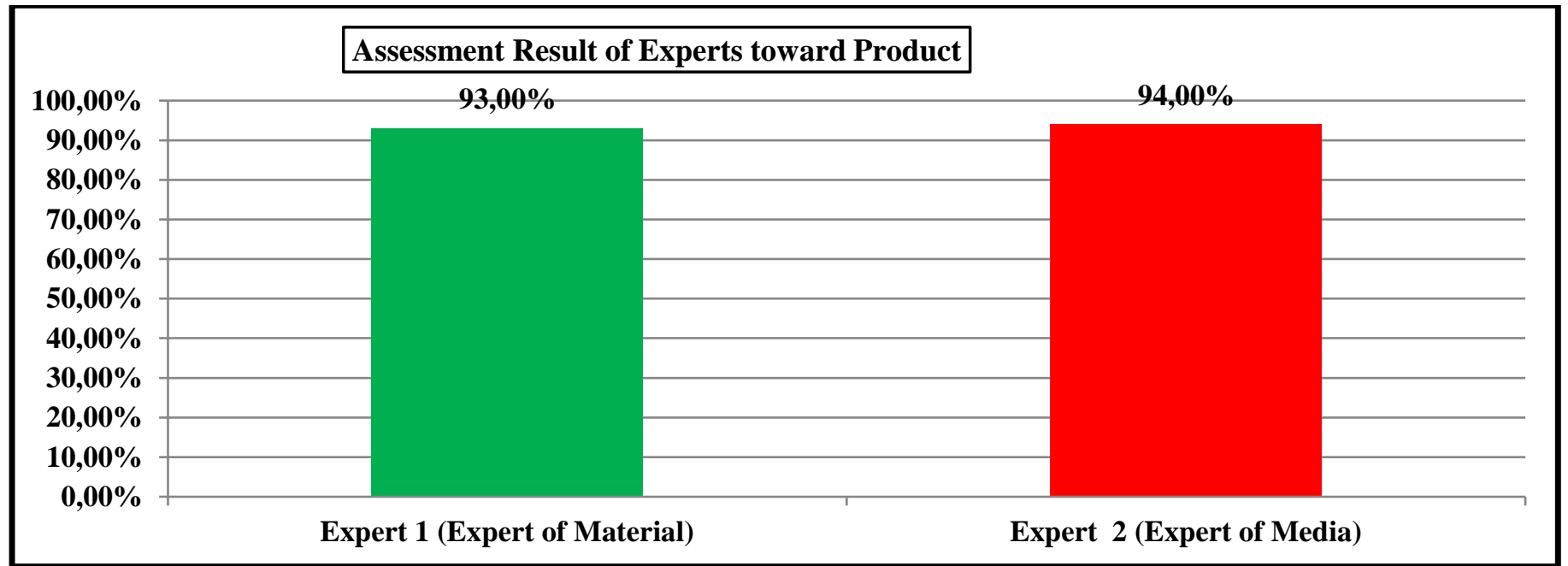

Graph 3. Assessment Result of Experts toward Product (Step 2)

From the two experts, it is obtained that the initial draft of the product is in a good category, then the product draft is revised according to the validation results. This shows that the expert's assessment of the initial draft that is made is feasible to be tested.

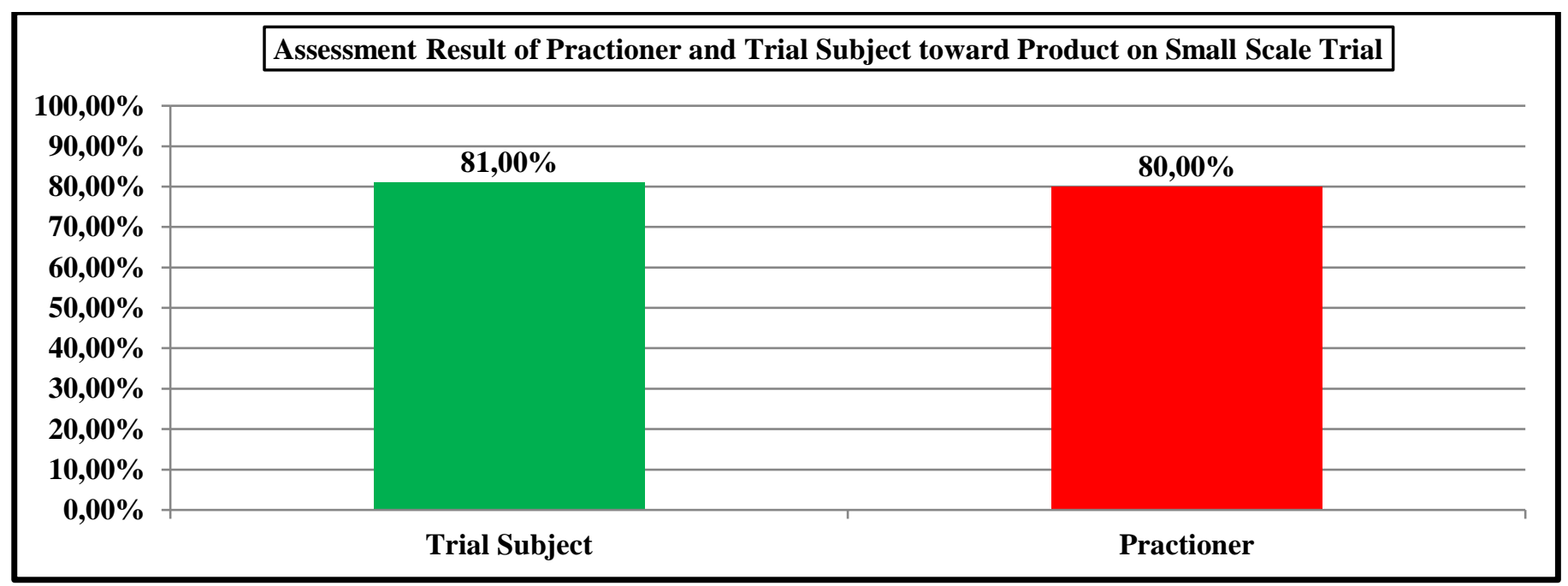

Graph 4. Assessment Result of Practioner and Trial Subject 


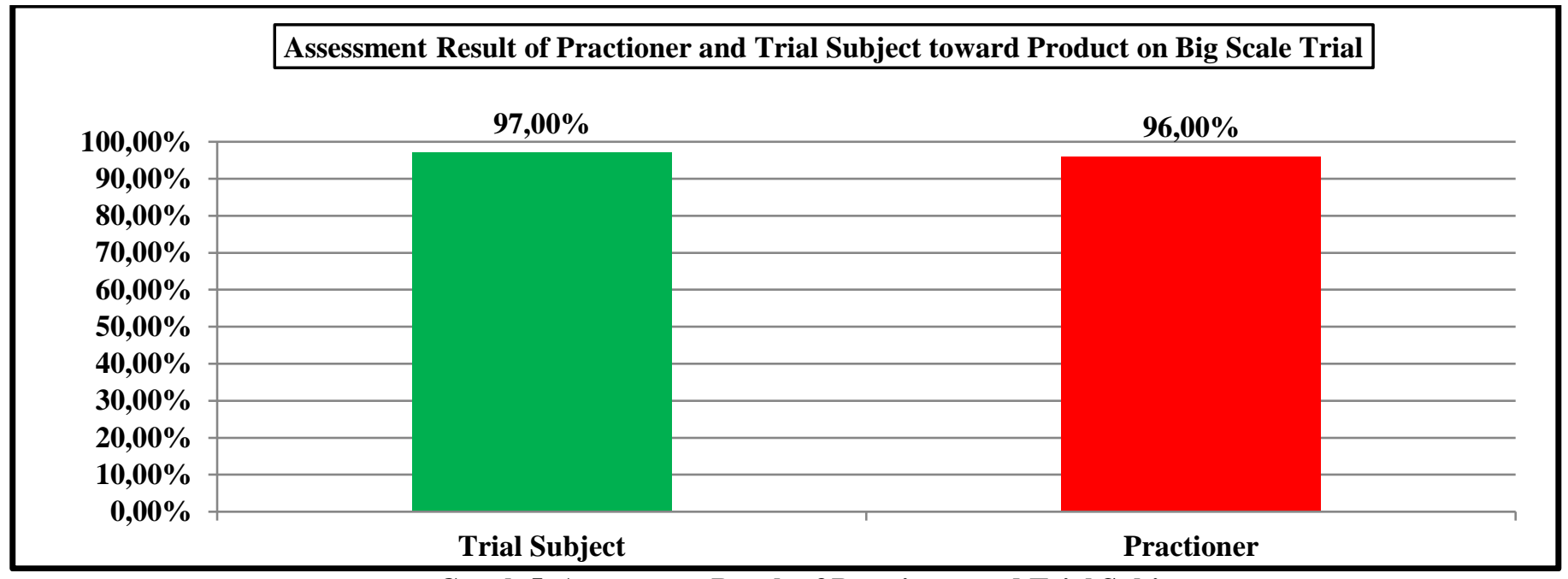

Graph 5. Assessment Result of Practioner and Trial Subject

The results of input and suggestions are used as evaluation materials by researchers to improve the products developed so that better products are produced. From the results of this large-scale trial, then the product is revised according to suggestions and input from experts. After being revised then the product is ready to be continued for product effectiveness testing.
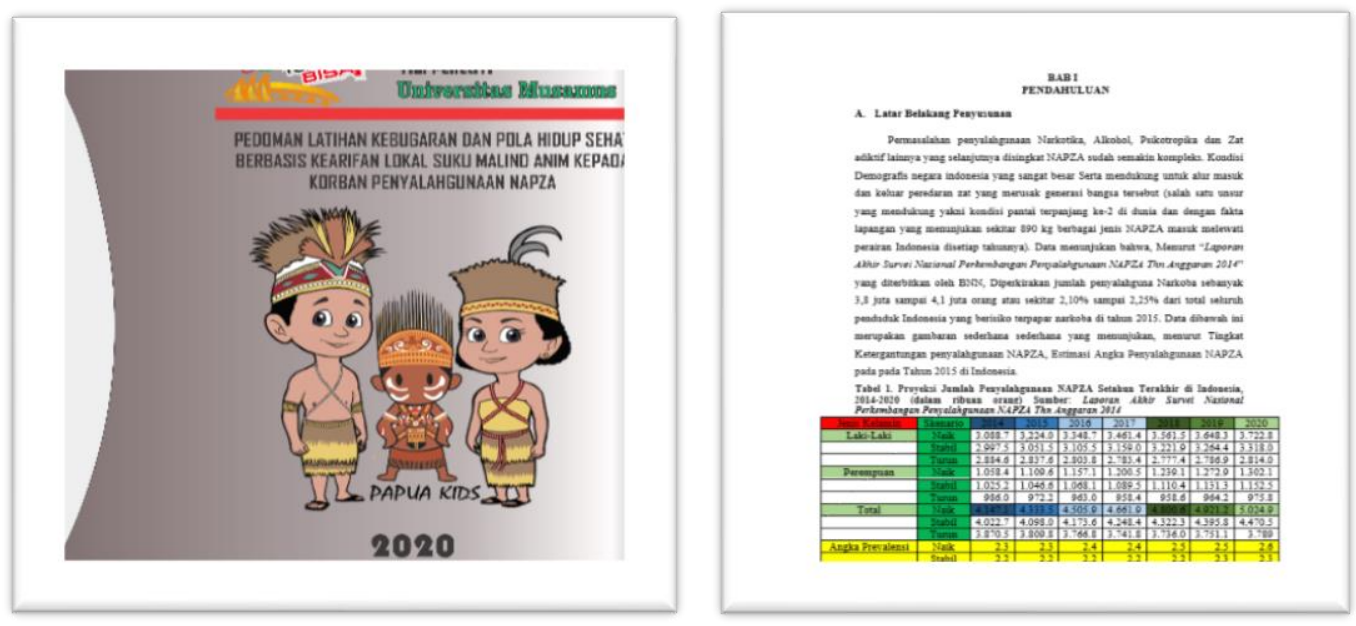

Figure 2. Revision Result of Development Product

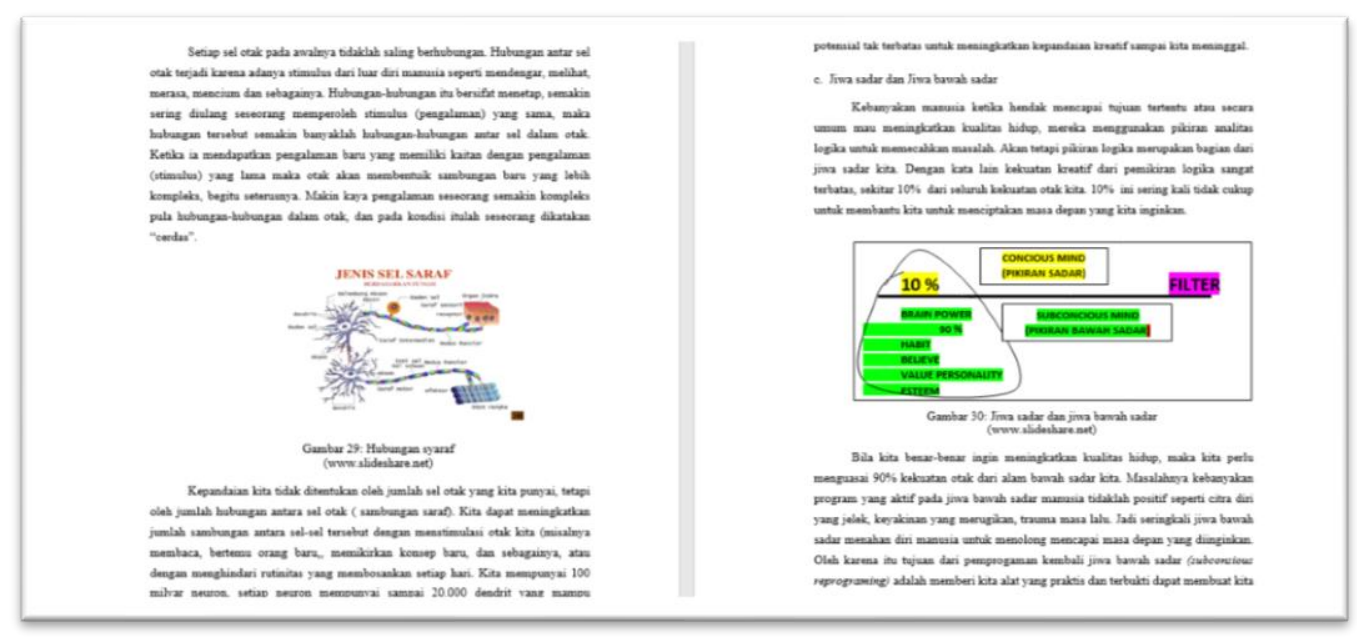

Figure 3. Revision Result of Development Product 
Based on suggestions and improvements in terms of language, adding a reference exercise program as a discussion reinforcement, adding a schematic relationship between body systems that support muscle contraction, adding medical evaluation notes for participants, physical examination sheets, and adding activities carried out in their environment, from this stage, continue researchers will revise the product for later testing. Based on the results of the second draft assessment, an expert assessment of the product in the form of Guidelines for Fitness Exercises and Healthy Lifestyles based on Local Wisdom Malind Anim to Victims of Drug Abuse in the Marind Tribe Community at the RI-PNG Border, Merauke Regency, Papua Province, considers that the product developed is very good, so no revision is required. The next stage in this research is the Final Product Study stage which consists of the implementation of research (Arikunto, 2013).

After the final product is produced in the form of guidelines for fitness training and a healthy lifestyle based on local wisdom by Malind Anim for victims of drug abuse in the Marind Tribe, the RI-PNG border, Merauke Regency, Papua Province, the next step is to test the effectiveness through the experimental method. Before the trial subject, in this case the Victims of Drug Abuse in the Marind Tribal Community, the RI-PNG Border, Merauke Regency, Papua Province, is given a fitness training program that has been developed, before the subject tries to measure the initial test / fitness pretest using the Cooper test (12 minutes run), then the subject tries to be given treatment for 6 meetings (in 3 weeks of implementation, 6 times of mentoring and evaluation, where in 1 week 5 times of activities in a series of training programs).

Warm-up: Jogging 2 rounds, Dynamic Stretching. Practice material: Spear-throwing rattan game, carries out 2 x 20 minutes, each player must move actively, may not walk. Warmup : Jogging 3 lap pool (Swamp Edge), Dynamic Stretching. Exercise material : Swamp Rewind (RunningABC) Duration of Exercise Time/Dose (6 sets/item) x 45 seconds, Full Speed Movement Rhythm, Each set rest 1 minute, Pause between Movement rest 3 minutes. Physical Activities Options: Harvesting sago, fishing, hunting and gardening with simple methods (Wambat method) Farming (sweet potato, cassava, kava, or sago, kumbili, sugarcane, sweet potato, fruit trees, coconut trees, medicinal plants, and other plants). Heating : Jogging 2 rounds, Dynamic Stretching Training Materials : Out Bond Activities : Trust Fall/Falling Tree (Team Trust), Water Transfer (Acceleration to reach the goal), Adventure/Route Tracing (Maturation Process and Building a Reliable Team) and the rest has been summarized periodically in the guidelines that the researcher developes, then given a posttest using the same test at the pretest. The product effectiveness test is carried out on 20 victims of drug abuse. Result Summary of the results of statistical descriptive analysis of pretest and posttest data on the fitness of victims of drug abuse presented as follows.

Table 6. Case Processing Summary

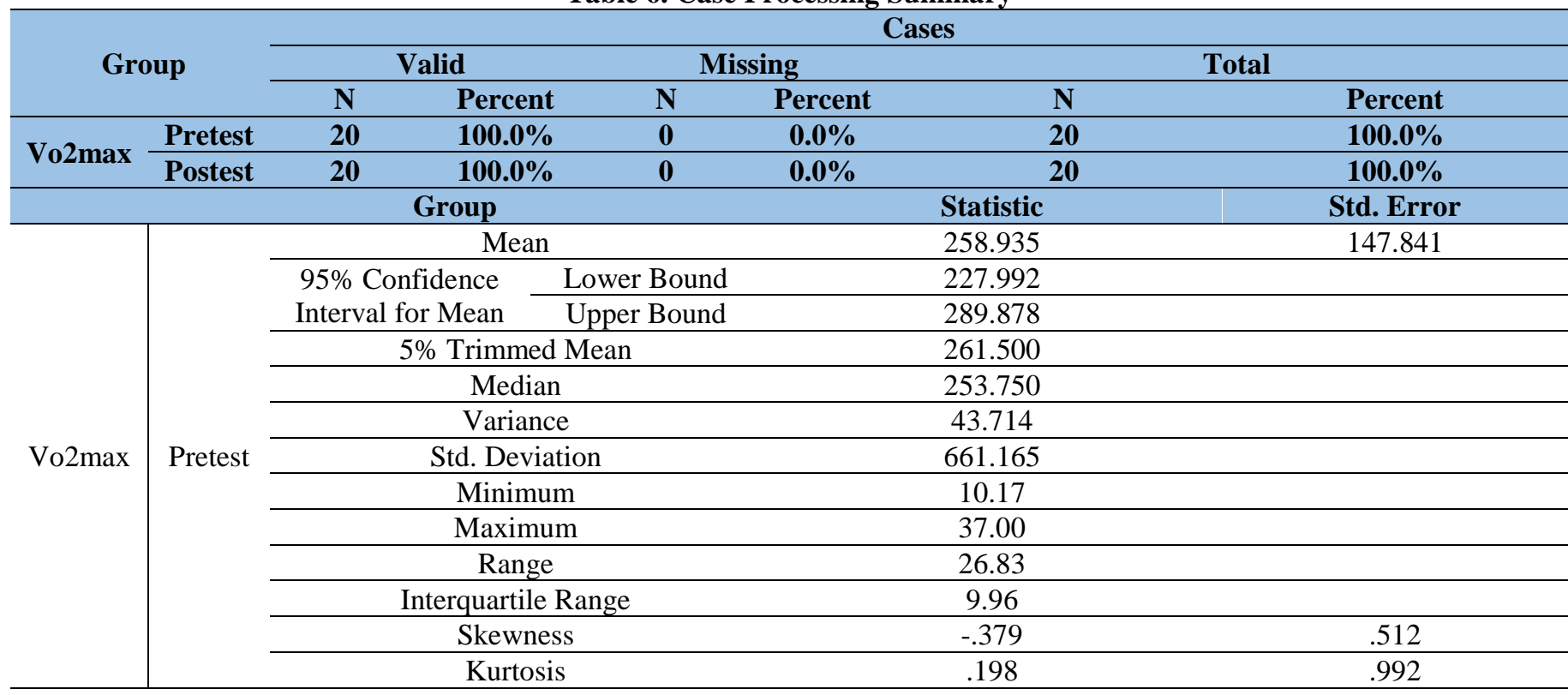




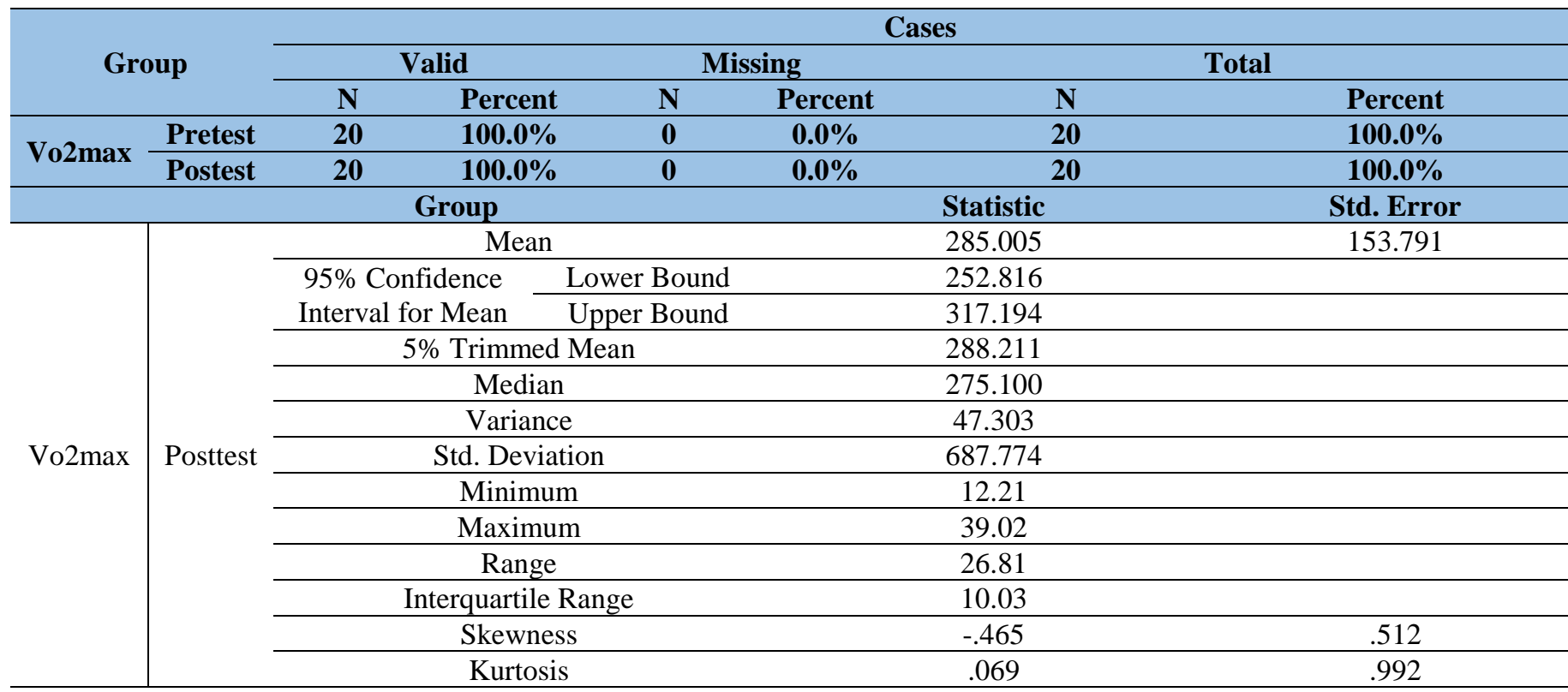

Table 7. Tests of Normality

\begin{tabular}{cccccccc}
\hline \multirow{3}{*}{ Vo2max } & \multirow{2}{*}{ Group } & \multicolumn{2}{c}{ Kolmogorov-Smirnov $^{\mathbf{a}}$} & \multicolumn{3}{c}{ Shapiro-Wilk } \\
\cline { 2 - 8 } & & Statistic & df & Sig. & Statistic & df & Sig. \\
\cline { 2 - 8 } & Pretest & .108 & 20 & $.200^{*}$ & .973 & 20 & .820 \\
\cline { 2 - 8 } & Postest & .126 & 20 & $.200^{*}$ & .955 & 20 & .445 \\
\hline
\end{tabular}

*. This is a lower bound of the true significance.

a. Lilliefors Significance Correction

Table 8. Test of Homogeneity of Variance

\begin{tabular}{|c|c|c|c|c|c|c|c|c|c|}
\hline & \multicolumn{4}{|c|}{ Levene Statistic } & df1 & df2 & \multicolumn{3}{|l|}{ Sig. } \\
\hline \multirow{4}{*}{ Vo2max } & \multicolumn{3}{|c|}{ Based on Mean } & .046 & 1 & 38 & \multicolumn{3}{|l|}{.832} \\
\hline & \multicolumn{3}{|c|}{ Based on Median } & .014 & 1 & 38 & \multicolumn{3}{|l|}{.907} \\
\hline & \multicolumn{3}{|c|}{$\begin{array}{c}\text { Based on Median and with } \\
\text { adjusted df }\end{array}$} & .014 & 1 & 37.767 & \multicolumn{3}{|l|}{.907} \\
\hline & \multicolumn{3}{|c|}{ Based on trimmed mean } & .072 & 1 & 38 & \multicolumn{3}{|l|}{.790} \\
\hline & \multicolumn{6}{|c|}{ Paired Differences } & t & df & $\begin{array}{l}\text { Sig. (2- } \\
\text { tailed) }\end{array}$ \\
\hline & \multirow{2}{*}{\multicolumn{2}{|c|}{ Mean }} & \multirow{2}{*}{$\begin{array}{c}\text { Std. } \\
\text { Deviatio } \\
\text { n }\end{array}$} & \multirow{2}{*}{$\begin{array}{l}\text { Std. } \\
\text { Error } \\
\text { Mean }\end{array}$} & \multicolumn{2}{|c|}{$\begin{array}{l}\text { 95\% Confidence Interval of the } \\
\text { Difference }\end{array}$} & & & \\
\hline & & & & & Lower & Upper & & & \\
\hline Pair 1 & est - PreTest & 260.700 & 117.111 & .26187 & 205.890 & 315.510 & 9.955 & 19 & .000 \\
\hline
\end{tabular}

By looking at the table above, the researcher concludes that the increase in VO2max can be increased by using the Cooper test. In addition, it can also be seen with the calculation results of a significance value of 0.000 . It can be concluded that the product in the form of a fitness exercise program guideline for victims of drug abuse that developed is effective for improving the fitness of victims of drug abuse. The product developed is suitable to be used as a model for increasing fitness and to increase physical activity so that boredom does not occur due to monotonous activities for victims of drug abuse in the RI-PNG Border Community of Merauke Papua. The products developed in this study have been tested on a small and large scale. The research data in the form of expert judgments, and the subject of trying to show the product in the form of a fitness exercise program guide for victims of drug abuse is worthy of being used as a model of an exercise program in the form of physical activity for victims of drug abuse. In addition to regulate a healthy diet, to prevent heart disease, and to keep the heart working better, the Indonesian Heart Foundation also recommends moving, exercising, working physically, and so on (Tritama, 2015; Adi et al., 2018; Werch et 
al., 2003). Regular physical activity (exercise) is very important to slow down the aging process in general and in particular to slow the decline in cardiorespiratory capacity (Malonda et al., 2012).

Regular exercise can also enhance lung vitality (Kalfa et al., 2012). The lungs are one of the respiratory organs that play a very important role in providing the oxygen needed by the body. About the role of exercise in increasing maximum oxygen consumption has been researched by Dr. Cooper. From the results of this study it is stated that people who exercise regularly have the ability to hold 1.5 more air than people who never exercise. The measurement of the amount of air or oxygen in the lungs is called VO2max, people who have a high VO2max can do more work before becoming tired, compared to people who have a lower VO2max, healthier and higher physical health a person has more oxygen can be processed by the body (Afriwardi, 2011). With regular exercise, you can take in a lot of oxygen, which means better blood circulation and muscle cells will get more oxygen from the capillaries. Thus, people who have VO2max are physiological organs of the body so that the capacity of these organs can be well maintained (Kalfa et al., 2012).

With a target to victims of drug abuse in the local community of Merauke, which has the main goal of growing awareness of the importance of maintaining individual health and inculcating disciplinary values through Physical Activities/Fitness (Nugroho \& Riyanto, 2020). Seeing the facts on the ground, in its implementation, fitness maintenance activities for Drug Abuse Victims that are programmed and integrated in the Recovery process have not been maximized. The limitation of this study is more fundamentally related to adjustment. Several rehabilitation programs that can be carried out for drug addicts are detoxification therapy, opioid substitution therapy, therapeutic community and anonymous 12-step narcotic therapy program. Each rehabilitation method can also be accompanied by psychosocial interventions such as brief intervention, basic counseling, motivational interviewing, CBT or relapse prevention (Takada \& Nishimura, 1962; Rini, 2012; Roi \& Bianchedi, 2008).

\section{CONCLUSION}

The results of the study show the feasibility and the effectiveness as a product of developing guidelines for fitness training and a healthy lifestyle based on local wisdom that can be used for victims of drug abuse in the RI-PNG border community in Merauke Papua. Giving treatment to research subjects there is an increase in VO2max can be increased by using the Cooper test. In addition, it can also be seen with the calculation results of a significance value of 0.000 . It can be concluded that the product in the form of a fitness exercise program guideline for victims of drug abuse that developed is effective for improving the fitness of victims of drug abuse. The first recommendation for further research from the researcher focuses on taking the experimental subject, which is a large group consisting of various local community groups in various areas within the Merauke district. Second, in taking samples from victims of drug abuse who have the same substance addiction background, taking into account biological age. Third, further researchers should add other, more modern tests in order to seek improvements from the implementation of the development program as a comparison in this study.

Therefore, the product of developing guidelines for fitness training and healthy lifestyles based on local wisdom that can be used for victims of drug abuse in this research process is an additional method to maintain the stability of addiction so that it does not relapse. The limitation in Product Development Research in this study is that there are no groups or agencies participating in the supervision of OGPZ who are conducting rehabilitation. There is no single form of therapy that is suitable for all individuals so that initial assessment with a personal approach plays an important role in determining the appropriate rehabilitation method for patients with drug use disorders.

\section{REFERENCES}

Adi, S., Soenyoto, T., \& Sulaiman, S. (2018). The Implementation of Media in Teaching and Learning of Physical, Sport, and Health Education Subject. Journal of Physical Education and Sports (JPES), 7(1), 13-21. https://doi.org/10.15294/JPES.V7I1.19740 
Afriwardi. (2011). Sports Medicine. Jakarta: Kedokteran EGC.

Anggraeni, N. D., Umar, A. N., Puhilan, Purwanto, S. E., Muhiriyah, E., Nugroho, G. W., Abdurahman, Septiana, L., Muammar, Voronika, V., Cornellya, Rusipah, Utoro, S., \& Mardin, N. (2017). Buku Pedoman Penyelidikan dan Penanggulangan Kejadian Luar Biasa Penyakit Menular dan Keracunan Pangan (Pedoman Epidemiologi Penyakit). Katalog Terbitan Kementerian Kesehatan Republik Indonesia, Edisi Revisi.

Azmiyati, S. R. (2014). Gambaran penggunaan NAPZA pada anak jalanan di Kota Semarang. KEMAS: Jurnal Kesehatan Masyarakat, 9(2), 137-143. https://doi.org/10.15294/kemas.v9i2.2841

Arikunto, S. (2013). Research Procedure A Practice Approach. Jakarta. PT. Rineka Cipta.

Khan, A. A. (2014). Effect of Physical Exercise of Asana Yoga and Aerobics on Hematological Variables. International Association of Computer Science in Sports, 13(1), 29-32.

Bostani, M., \& Saiiari, A. (2011). Comparison emotional intelligence and mental health between athletic and non-athletic students. Procedia-Social and Behavioral Sciences, 30, 2259-2263. https://doi.org/10.1016/j.sbspro.2011.10.441

Calmels, C., Berthoumieux, C., \& D'Arripe-Longueville, F. (2004). Effects of an imagery training program on selective attention of national softball players. Sport Psychologist, 18(3), 272-296. https://doi.org/10.1123/tsp.18.3.272

Sukadiyanto., \& Muluk. (2011). Introduction to Theory and Physical Training Methodology. Bandung: CV Lubuk Agung.

Giriwijoyo, S. (2017). Fisiologi Kerja dan Olahraga: Fungsi Tubuh Manusia Pada Persada, Kerja dan Olahraga. Jakarta: PT Raja Grafindo.

Kalfa, T. A., Risinger, M. A., Pushkaran, S., Dexheimer, P., Husami, A., Kissell, D., Joiner, C. H., Keddache, M., \& Zhang, K. (2012). Next Generation Sequencing for Diagnostic Testing of Erythrocyte Cytoskeleton Disorders. Blood, 120(21), 976-976. https://doi.org/10.1182/blood.v120.21.976.976

Lahinda, J., Riyanto, P., Nugroho, A. I., \& Pasinringi, S. A. (2020). Effect of healthy living behaviour on physical fitness. Enfermeria Clinica, 30. 54-58. https://doi.org/10.1016/j.enfcli.2020.06.013

Werch, C., Moore, M., DiClemente, C. C., Owen, D. M., Jobli, E., \& Bledsoe, R. (2003). A sport-based intervention for preventing alcohol use and promoting physical activity among adolescents. Journal of School Health, 73(10), 380-388.

Malonda, N. S. H., Dinarti, L. K., \& Pangastuti, R. (2012). Pola makan dan konsumsi alkohol sebagai faktor risiko hipertensi pada lansia. Jurnal Gizi Klinik Indonesia, 8(4), 202-212. https://doi.org/10.22146/ijcn.18219

Nainggolan, T. (2011). Hubungan antara Kepercayaan Diri dengan Kecemasan Sosial pada Pengguna NAPZA: Penelitian di Balai Kasih Sayang Parmadi Siwi. Sosio Konsepsia, 16(2), 161-174. https://doi.org/10.33007/ska.v16i2 
Nugroho, A. I., \& Fadlih, A. M. (2019). Pengaruh Sumber Belajar Dasar Gerak Softball Terhadap Kemampuan Kognitif Mahasiswa PJKR UNMUS. Musamus Journal of Physical Education and Sport (MJPES), 2(01), 19-27. https://doi.org/10.35724/mjpes.v2i01.2074

Nugroho, A. I., \& Riyanto, P. (2020). Development of Fitting Training Programs for Victims of Drug Abuse in the Social and Human Resource Rehabilitation Center BRSPP DIY. 3rd International Conference on Social Sciences (ICSS 2020), 452-455.

Nugroho, A. I., Riyanto, P., Lahinda, J., \& Hidayat, S. H. (2020). Effectiveness of physical condition training on the fitness of drug abuse victims, BRSPP Yogyakarta. Enfermería Clínica, 30, 63-66. https://doi.org/10.1016/j.enfcli.2020.06.015

Osborne, A., Sherry, E., \& Nicholson, M. (2016). Celebrity, scandal and the male athlete: a sport media analysis. European Sport Management Quarterly, 16(3), 255-273. https://doi.org/10.1080/16184742.2016.1164214

Rini, H. (2012). Perilaku Kriminal Pada Pecandu Alkohol. https://adoc.pub/perilaku-kriminal-pada-pecandualkohol.html.

Roi, G. S., \& Bianchedi, D. (2008). The science of fencing: Implications for performance and injury prevention. Sports Medicine, 38(6), 465-481. https://doi.org/10.2165/00007256-200838060-00003

Shen, B., \& Chen, A. (2007). An examination of learning profiles in physical education. Journal of Teaching in Physical Education, 26(2), 145-160. https://doi.org/10.1123/jtpe.26.2.145

Sugiyono. (2011). Educational Research Methods (Quantitative, Qualitative and $R \& D$ Approaches). Bandung: Alfabeta.

Takada, A., \& Nishimura, H. (1962). Researches on Chemotherapeutic Drugs against Viruses. XXXIV. Syntheses and Antiviral Activity of 10-( $\omega$-Dialkylaminoalkyl)-alkylphenothiazine and N-Substituted 10Glycyl-alkylphenothiazine. Chemical and Pharmaceutical Bulletin, 10(1), 1-8. https://doi.org/10.1248/cpb.10.1

Tritama, T. K. (2015). Konsumsi Alkohol dan Pengaruhnya terhadap Kesehatan. Journal Majority, 4(8), $7-$ 10.

Utina, S. S. (2012). Alkohol dan Pengaruhnya Terhadap Kesehatan Mental. Jurnal Health and Sport, 5(2).1120.

Werch, C., Moore, M., DiClemente, C. C., Owen, D. M., Jobli, E., \& Bledsoe, R. (2003). A sport-based intervention for preventing alcohol use and promoting physical activity among adolescents. Journal of School Health, 73(10), 380-388. https://doi.org/10.1111/j.1746-1561.2003.tb04181.x

Yarman. (2013). Implikasi Kearifan Lokal bagi Pengelolaan Taman Nasional Wasur. Media Konservasi, 18(3), 112-119. https://doi.org/10.29244/medkon.18.3.\%25p 